University of Nebraska - Lincoln

DigitalCommons@University of Nebraska - Lincoln

Biological Systems Engineering: Papers and

Publications

Biological Systems Engineering

2-1993

\title{
Critical Shear Stress and Critical Flow Rates for Initiation of Rilling
}

John E. Gilley

University of Nebraska-Lincoln, john.gilley@ars.usda.gov

W. J. Elliot

Ohio State University

J. M. Laflen

Purdue University - Calumet Campus

J. R. Simanton

United States Department of Agriculture

Follow this and additional works at: https://digitalcommons.unl.edu/biosysengfacpub

Part of the Biological Engineering Commons

Gilley, John E.; Elliot, W. J.; Laflen, J. M.; and Simanton, J. R., "Critical Shear Stress and Critical Flow Rates for Initiation of Rilling" (1993). Biological Systems Engineering: Papers and Publications. 116.

https://digitalcommons.unl.edu/biosysengfacpub/116

This Article is brought to you for free and open access by the Biological Systems Engineering at DigitalCommons@University of Nebraska - Lincoln. It has been accepted for inclusion in Biological Systems Engineering: Papers and Publications by an authorized administrator of DigitalCommons@University of Nebraska Lincoln. 
$[1]$

\title{
Critical shear stress and critical flow rates for initiation of rilling
}

\author{
J.E. Gilley ${ }^{\mathrm{a}}$, W.J. Elliot ${ }^{\mathrm{b}}$, J.M. Laflen ${ }^{\mathrm{c}}$ and J.R. Simanton ${ }^{\mathrm{d}}$ \\ "USDA-ARS, University of Nehraska, Lincoln, NE 68583, USA \\ ${ }^{\mathrm{h}}$ Agricultural Engineering Department, Ohio State University. Columbus, OH 43210, USA \\ 'USDA-ARS, Purdue University, W. Lafaverte, IN 47907, USA \\ ${ }^{" U S D A-A R S}$. Tucsom, AZ 85719, USA
}

(Received 5 May 1992; accepted 8 June 1992)

\section{ABSTRACT}

Gillcy, J.E., Elliot, W.J., Laflen. J.M. and Simanton, J.R., 1993. Critical shear stress and critical flow rates for initiation of rilling. J. Hydrol., 142: 251-271.

This study was conducted to identify critical shear stress and critical flow rates required to initiate rilling on selected sites. The data used in this investigation were collected from soils located throughout the USA where crop residues had been removed, and moldboard plowing and disking had occurred. Runofl and soil loss measurements were made on sites where simulated rainfall wats applied to preformed rills. Multiple regression analyses were used to relate critical shear stress values and critical flow rates to selected soil properties. The soil-based regression equations were found to provide reliable estimates. Information identified in this study will improve our ability to understand and properly model upland runoff and erosion processes.

\section{INTROIDUCTION}

The force per unit wetted area that acts on a surface is defined as shear stress, $\tau$, and is expressed as

$\tau=\gamma S$

where $\gamma$ is the specific weight of water, $y$ is the flow depth, and $S$ is the slope gradient. Critical shear stress, $\tau_{c}$, occurs when the shear force exceeds the critical limit for soil detachment. The beginning of motion of soil particles is difficult to define. The most dependable data concerning incipient soil particle movement have resulted from laboratory experiments.

Several equations for estimating bed load sediment transport have been

Correspondence to: J.E. Gilley, USDA-ARS, University of Nebraska, Lincoln, NE 68583 , USA 
derived which use shear stress as an independent variable (Laursen, 1958). These relations were originally developed to predict sediment transport in stream and river systems. Foster (1982) used similar concepts to derive the following equation for estimating rill sediment detachment capacity, $D_{c}$ :

$D_{\mathrm{c}}=K_{\mathrm{r}}\left(\tau-\tau_{\mathrm{c}}\right)$

where $K_{\mathrm{r}}$ is the rill soil erodibility factor. This equation was used in an erosion prediction model described by Nearing et al. (1989). Equation (2) can be rearranged to yield

$\tau=\frac{D_{\mathrm{c}}}{K_{\mathrm{r}}}+\tau_{\mathrm{c}}$

The intercept of eqn. (3) is critical shear stress, and the inverse of the slope is the rill soil erodibility factor.

Schoklitsch (1957) developed an equation which related bed load sediment transport to flow rate and slope gradient. A similar relation could be used to predict rill sediment detachment capacity where

$D_{\mathrm{c}}=K_{\mathrm{f}}\left(Q S^{3 / 2}-Q_{\mathrm{c}} S^{3 / 2}\right)$

and $K_{\mathrm{f}}$ is the flow-related rill soil erodibility factor, $Q$ is the flow rate, and $Q$ is the critical flow rate.

Equation (4) can be rearranged to yield

$Q=\frac{1}{K_{\mathrm{f}}}\left(\frac{D_{\mathrm{c}}}{S^{3 / 2}}\right)+Q_{\mathrm{c}}$

Critical flow rate is represented by the intercept of eqn. (5), and the inverse of the slope is the flow-related rill soil erodibility factor.

\section{PROCEDURE}

Sediment detachment capacity was determined by Elliot et al. (1989) on soils located throughout the USA. The location, slope and particle size analyses of the soils are presented in Table 1 . The soils were selected to cover a broad range of physical, chemical, mineralogical and biological properties. These properties resulted from diverse soil-forming factors acting through time, including climate, parent material, vegetation, biological activity, and topography. Each of the soils is considered to be of regional or national importance.

The study areas were located on uniform slopes having homogeneous soil characteristics. Either corn or small grains had been planted the previous year. All surface residue was first removed, and the area was then moldboard 
TABLE

Location, slope and particle size analyses of selected soils

\begin{tabular}{|c|c|c|c|c|c|c|}
\hline \multirow[t]{3}{*}{ Soil } & \multicolumn{2}{|l|}{ Location } & \multirow{3}{*}{$\begin{array}{l}\text { Average rill } \\
\text { slope }(\%)\end{array}$} & \multirow{2}{*}{\multicolumn{3}{|c|}{$\begin{array}{l}\text { Particle size analysis } \\
\text { (\% by weight) }\end{array}$}} \\
\hline & \multirow{2}{*}{ County } & \multirow{2}{*}{ State } & & & & \\
\hline & & & & Sand & Silt & Clay \\
\hline Academy & Fresno & $\mathrm{CA}$ & 4.5 & 62.7 & 29.1 & 8.2 \\
\hline Amarillo & Howard & $\mathrm{TX}$ & 3.6 & 85.0 & 7.7 & 7.3 \\
\hline Barnes-MN & Stcvens & $\mathrm{MN}$ & 8.3 & 48.6 & 34.4 & 17.0 \\
\hline Barnes-ND & Sheridan & ND & 5.8 & 39.5 & 36.0 & 24.5 \\
\hline Caribou & Aroostook & $\mathrm{ME}$ & 8.8 & 47.0 & 40.3 & 12.7 \\
\hline Cecil & Oconee & GA & 4.5 & 64.6 & 15.6 & 19.8 \\
\hline Collamer & Tompkins & NY & 8.7 & 7.0 & 78.0 & 15.0 \\
\hline Frederick & Washington & MD & 12.8 & 25.1 & 58.3 & 16.6 \\
\hline Gaston & Rown & $\mathrm{NC}$ & 6.4 & 35.5 & 25.4 & 39.1 \\
\hline Grenada & Panola & MS & 8.7 & 2.0 & 77.8 & 20.2 \\
\hline Heiden & Falls & $\mathrm{TX}$ & 3.9 & 8.6 & 38.3 & 53.1 \\
\hline Hersh & Valley & $\mathrm{NE}$ & 6.6 & 74.4 & 15.9 & 9.7 \\
\hline Hiwassec & Oconce & GA & 4.0 & 63.7 & 21.6 & 14.7 \\
\hline Lewisburg & Whitley & IN & 7.5 & 38.5 & 32.2 & 29.3 \\
\hline Manor & Howard & MD & 8.6 & 43.6 & 30.7 & 25.7 \\
\hline Mexico & Boone & $\mathrm{MO}$ & 3.9 & 5.3 & 68.7 & 26.0 \\
\hline Miami & Montgomery & IN & 5.8 & 4.2 & 72.7 & 23.1 \\
\hline Miamian & Montgomery & $\mathrm{OH}$ & 8.9 & 30.6 & 44.1 & 25.3 \\
\hline Nansene & Whitman & WA & 6.1 & 20.1 & 68.8 & 11.1 \\
\hline Opequon & Allegany & $\mathrm{MD}$ & 12.0 & 37.7 & 31.2 & 31.1 \\
\hline Palouse & Whitman & WA & 6.5 & 9.8 & 70.1 & 20.1 \\
\hline Pierre & Jackson & $\mathrm{SD}$ & 6.6 & 9.6 & 40.9 & 49.5 \\
\hline Portncuf & Twin Falls & ID & 5.6 & 21.5 & 67.4 & 11.1 \\
\hline Sharpsburg & Lancaster & NE & 5.7 & 4.8 & 55.4 & 39.8 \\
\hline Sverdrup & Grant & $\mathrm{MN}$ & 4.2 & 75.3 & 16.8 & 7.9 \\
\hline Tifton & Worth & $\mathrm{GA}$ & 4.6 & 86.4 & 10.8 & 2.8 \\
\hline Whitney & Fresno & $\mathrm{CA}$ & 7.4 & 71.0 & 21.8 & 7.2 \\
\hline Williams & Sheridan & ND & 5.1 & 41.6 & 32.4 & 26.0 \\
\hline Woodward & Harper & $\mathrm{OK}$ & 7.1 & 43.7 & 42.4 & 13.9 \\
\hline Zahl & Roosevelt & MT & 7.6 & 46.3 & 29.7 & 24.0 \\
\hline
\end{tabular}

plowed 3-12 months before the tests were conducted. After plowing, sites were disked lightly then maintained free of vegetation either by tillage or application of herbicide.

Soil samples for site characterization were obtained and analyzed using standard procedures (Soil Survey Staff, 1984). Samples were collected at a 
TABLE 2 Journal of Hydrology 142 (1993): 251-271

Mcan, minimum and maximum values of selected soil propertics at the study sites

\begin{tabular}{|c|c|c|c|}
\hline Soil property & Mean & Minimum & Maximum \\
\hline Aluminum ${ }^{a}$ & 0.15 & 0.03 & 0.50 \\
\hline Calcium ${ }^{\mathrm{h}}$ & 9.0 & 0.0 & 33 \\
\hline Cation exchange capacity" & 15 & 1.7 & 39 \\
\hline Clay ${ }^{\mathrm{a}}$ & 21 & 2.8 & 53 \\
\hline Coefficient of linear extensibility & 0.03 & 0.00 & 0.10 \\
\hline Iron & 1.2 & 0.20 & 4.5 \\
\hline Magnesiumb & 2.7 & 0.10 & 9.2 \\
\hline Organic carbon" & 1.2 & 0.16 & 3.3 \\
\hline Potassium ${ }^{\mathrm{h}}$ & 0.65 & 0.10 & 2.5 \\
\hline Sand" & 40 & 2.0 & 91 \\
\hline Silt $^{\mathrm{a}}$ & 39 & 5.5 & 78 \\
\hline Sodium" & 0.09 & 0.00 & 0.60 \\
\hline Soil water content at $0.3 \mathrm{MPa}^{\mathrm{i}}$ & 21 & 4.9 & 34 \\
\hline Soil water content at $1.5 \mathrm{MPa}^{*}$ & 9.6 & 1.1 & 19 \\
\hline Very fine sand ${ }^{a}$ & 12 & 1.1 & 44 \\
\hline Water dispersible clay ${ }^{2}$ & 8.3 & 1.1 & 25 \\
\hline
\end{tabular}

"Values in $\%$

"Values in centimoles per kilogram.

"Values in centimeters per entimeter.

central location and at several satellite points as is typical in a standard soil survey. The following properties were measured at each site: cation exchange capacity; coefficient of linear extensibility; dithionite-citrate extractable aluminum and iron content; exchangeable calcium, magnesium, potassium and sodium; percentage of sample consisting of clay, organic carbon, sand, silt, very fine sand and water dispersible clay; and water retained by a soil sample at 0.3 and $1.5 \mathrm{MPa}$ tension. Mean, minimum and maximum values of selected soil properties at the study sites are shown in Table 2.

A plot diagram of a rainfall simulation site is shown in Fig. 1. The study areas were disked immediately preceding testing. Six rills, $0.46 \mathrm{~m}$ across the slope by $9.0 \mathrm{~m}$ long, were formed using a ridging tool mounted on a small tractor. A sheet metal border was placed at the top of each rill and a runoff collection device was located at the bottom. Details and dimensions of the rill plots are presented in Fig. 2.

A portable rainfall simulator designed by Swanson (1965) was used to apply rainfall at an intensity of approximately $62 \mathrm{~mm} \mathrm{~h}{ }^{1}$. Erosion data collection was divided into three periods: (1) rainfall only until equilibrium of rill flow occurred; (2) rainfall plus flow addition in increments at the top of 


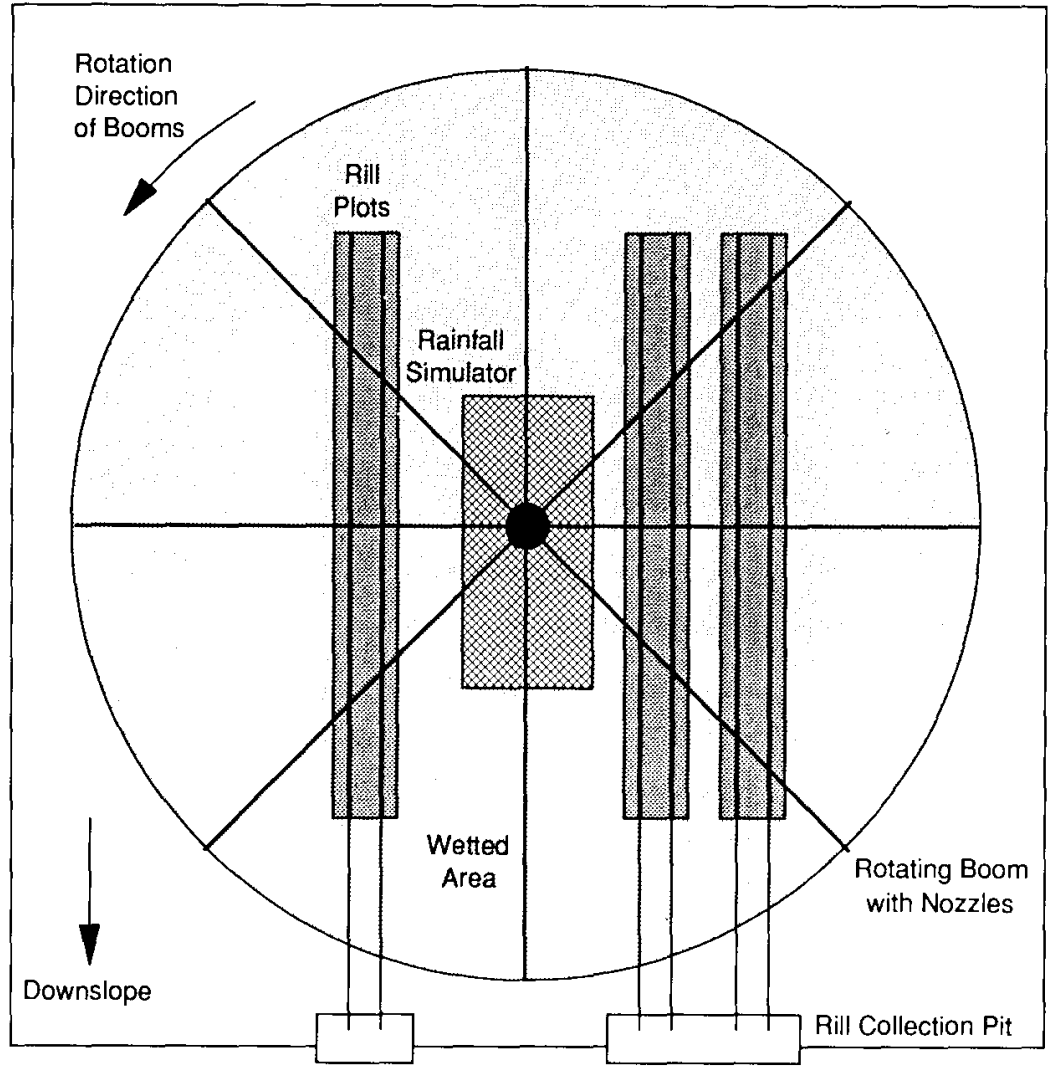

lïg. 1. Plot diagram of a rainfall simulation site.

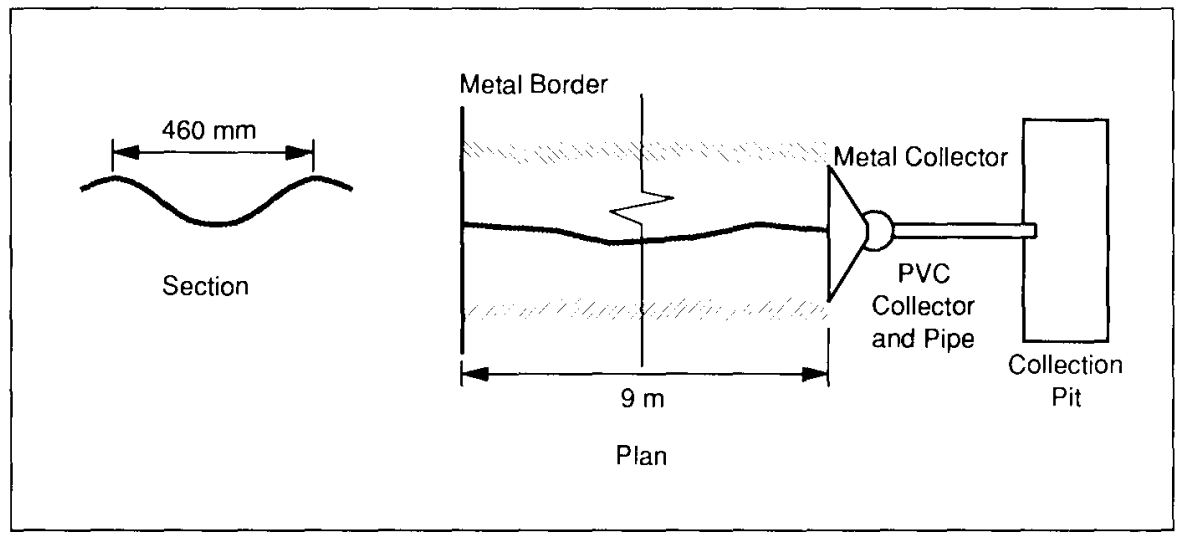

Fig. 2. Details and dimensions of the rill plots. 


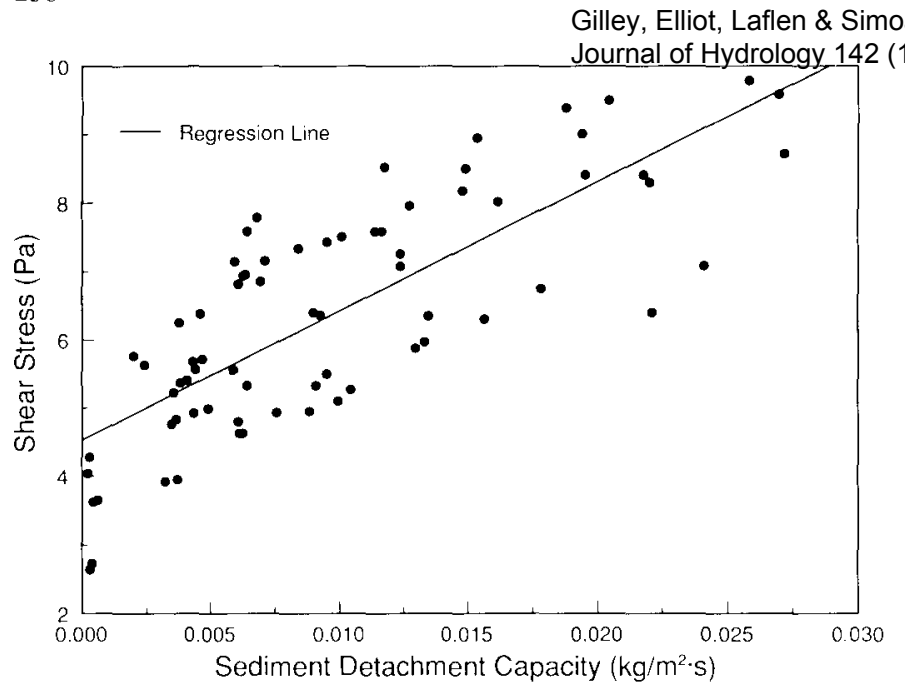

Fig. 3. Shear stress vs. sediment detachment capacity for a Barnes soil in North Dakota.

each rill; (3) flow addition at the top of each rill without rainfall. Only data obtained during the third simulation period were used in this investigation.

Flow was added to the top of each rill at rates of $7,14,21,28$ and $351 \mathrm{~min}$ '. For each inflow rate increment, two (replicate) runoff samples were obtained from each rill under equilibrium conditions for determination of flow rate and sediment concentration. Each rill was then treated as a separate replication in the statistical analyses. Additional details concerning experimental procedures are given by Elliot et al. (1989).

\section{CRITICAL SHEAR STRESS}

Identifying critical shear stress

Shear stress vs. detachment capacity for a Barnes soil in North Dakota is shown in Fig. 3. Results obtained for this soil are also representative of the other experimental sites. It can be seen from Fig. 3 that a linear equation can be used to represent the relationship between shear stress and sediment detachment capacity. The point where the regression line intercepts the $y$-axis represents critical shear stress for initiation of rilling. Critical shear stress for the Barnes soil in North Dakota was 4.53 Pa.

The critical shear stress values shown in Table 3 were obtained using linear regression analyses. Positive values of critical shear stress were found for each of the experimental soils. Critical shear stress ranged from $1.73 \mathrm{~Pa}$ for the Sverdrup soil to $10.6 \mathrm{~Pa}$ for the Opequon soil. 
TABLE 3

Statistical analyses of equations used to relate rill shear stress to detachment capacity

\begin{tabular}{lll}
\hline Soil & $\tau_{\mathrm{c}}{ }^{a}$ & $\begin{array}{l}K_{\mathrm{r}}{ }^{\mathrm{a}} \\
\left(\mathrm{Pa} \mathrm{m}^{-1}\right)\end{array}$ \\
& $\begin{array}{l}\text { (multiply by } \\
\left.10^{2}\right)\end{array}$ & $r^{2}$ \\
\hline
\end{tabular}

\begin{tabular}{lcll}
\hline Academy & 1.82 & 0.704 & 0.833 \\
Amarillo & 1.92 & 4.76 & 0.634 \\
Barnes-MN & 5.70 & 1.30 & 0.638 \\
Barnes-ND & 4.53 & 0.529 & 0.611 \\
Caribou & 7.07 & 0.276 & 0.610 \\
Cecil & 2.56 & 0.455 & 0.624 \\
Collamer & 5.86 & 1.32 & 0.718 \\
Frederick & 9.54 & 0.402 & 0.644 \\
Gaston & 2.54 & 0.300 & 0.613 \\
Grenada & 6.39 & 0.725 & 0.606 \\
Heiden & 1.94 & 0.752 & 0.682 \\
Hersh & 3.14 & 1.49 & 0.621 \\
Hiwassec & 1.94 & 0.885 & 0.733 \\
Lewisburg & 4.87 & 0.970 & 0.660 \\
Manor & 6.77 & 1.01 & 0.813 \\
Mexico & 1.90 & 4.33 & 0.648 \\
Miami & 4.64 & 2.27 & 0.700 \\
Miamian & 7.22 & 1.08 & 0.626 \\
Nansene & 3.58 & 2.04 & 0.607 \\
Opequon & 10.6 & 1.05 & 0.614 \\
Palouse & 4.35 & 0.925 & 0.735 \\
Portneuf & 4.30 & 2.08 & 0.702 \\
Sharpsburg & 4.46 & 0.529 & 0.665 \\
Sverdrup & 1.73 & 0.901 & 0.607 \\
Tifton & 2.20 & 0.746 & 0.638 \\
Whitney & 2.65 & 1.75 & 0.726 \\
Williams & 3.81 & 0.518 & 0.663 \\
Woodward & 3.61 & 1.18 & 0.606 \\
Zahl & 4.51 & 1.85 & 0.635 \\
\hline - & & &
\end{tabular}

${ }^{a}$ Regression coefficients $\tau_{\mathrm{c}}$ and $K_{\mathrm{r}}$ are used in the equation $\tau=\frac{1}{K_{\mathrm{r}}}\left(D_{\mathrm{c}}\right)+\tau_{\mathrm{c}}$

where shear stress and detachment eapacity are in Pascals and kilograms per square meter per second, respectively. 


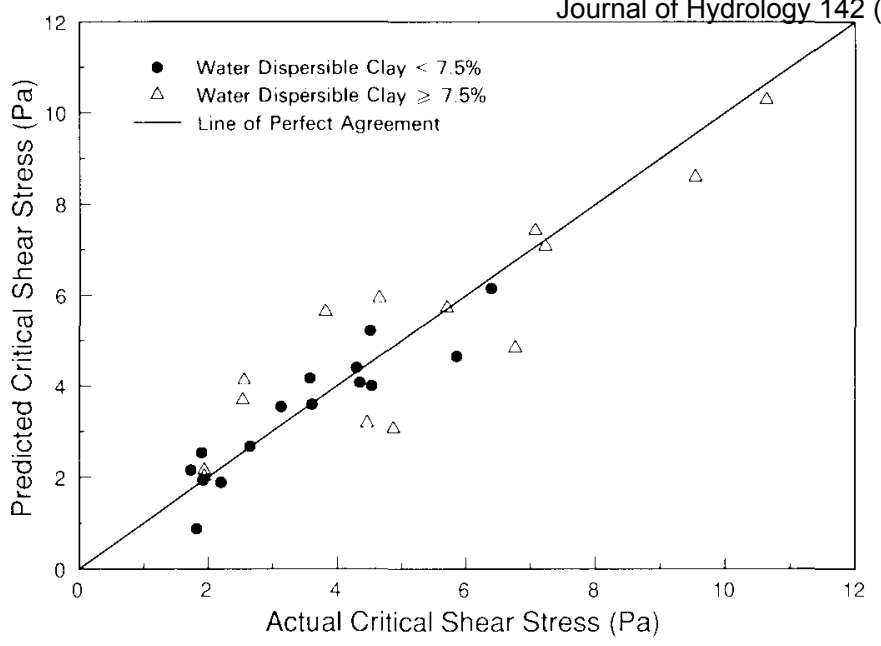

Fïg. 4. Predicted vs actual critical shear stress values.

Relating critical shear stress to soil properties

Step-wise multiple regression analyses were performed to relate critical shear stress values identified in Table 3 to soil properties presented in Table 2. Statistical analyses suggested that critical shear stress was significantly correlated to water dispersible clay. For soils with water dispersible clay content of less than $7.5 \%$,

$\tau_{\mathrm{c}}=+0.216$ (clay) -183 (coefficient of linear extensibility)

$$
+0.412 \text { (soil water content at } 1.5 \mathrm{MPa})+0.780
$$

where clay and soil water content at 1.5 MPa are given as pereentages, and coefficient of linear extensibility is in centimeters per centimeter. All the regression coeflicients shown in eqn. (6) were significantly different from zero at the $95 \%$ confidence level. For soils with water dispersible clay content of $7.5 \%$ or greater,

$$
\begin{aligned}
\tau_{c}= & 0.296(\text { calcium })+1.53 \text { (iron) }+7.75 \text { (organic carbon) } \\
& -11.4 \text { (potassium) }-0.535 \text { (very fine sand) }-0.208
\end{aligned}
$$

where calcium and potassium content are in centimoles per kilogram, and iron, organic carbon and very fine sand are given as percentages. All the regression coefficients shown in eqn. (7) were significantly different from zero at the $95 \%$ confidence level.

Values of $\tau_{c}$ were calculated for each of the experimental soils using soil survey data and eqns. (6) and (7). Results of the analyses are shown in Fig. 4. It can be seen from Fig. 4 that predicted and actual values of $\tau_{c}$ were similar. 
Linear regression analyses were employed to compare predicted and actual values of $\tau_{c}$. Results of the statistical analyses are shown in Table 4. Coefficient of determination values of 0.859 and 0.808 were found for eqns. (6) and (7), respectively.

The Students $t$-test was used to evaluate the hypotheses that the regression coefficients shown in Table 4 equal unity and the intercepts equal zero at the $95 \%$ confidence level. The slopes were not significantly different from unity, nor were the intercepts significantly different from zero. Thus, analyses of the experimental data suggests that eqns. (6) and (7) can be used to estimate $\tau_{c}$.

RILL SOIL ERODIBILITY FACTOR

\section{Determining the rill soil erodibility factor}

Figure 3 shows shear stress versus sediment detachment capacity for a Barnes soil in North Dakota. The inverse of the slope of the regression line presented in Fig. 3 is defined as the rill soil erodibility factor. For the Barnes soil in North Dakota, the slope of the regression line was 189, which corresponds to a rill soil erodibility factor of $0.00529 \mathrm{~s} \mathrm{~m}$ '.

Linear regression analyses were used to determine rill soil erodibility factors for each of the other study locations. Results of the regression analyses are shown in Table 3 . Rill soil erodibility factors were found to vary from $0.00276 \mathrm{sm}^{1}$ for the Caribou soil to $0.0476 \mathrm{sm}$ ' for the Amarillo soil.

\section{Relating rill soil erodihility factors to soil propertics}

Rill soil erodibility factors identified in Table 3 were related to soil properties presented in Table 2 using step-wise multiple regression analyses. The rill soil erodibility factors were found to be significantly correlated to soil water content at $0.3 \mathrm{MPa}$. For sites with soil water content at $0.3 \mathrm{MPa}$ of $23.0 \%$ or less,

$K_{\mathrm{r}}=-0.00294$ (iron) $+0.121($ sodium $)+0.0113$

where iron content is given as a percentage and sodium concentration is in centimoles per kilogram. The regression coefficients shown in eqn. (8) were significantly different from zero at the $99 \%$ confidence level.

For sites with a soil water content at $0.3 \mathrm{MPa}$ greater than $23.0 \%$

$$
\begin{aligned}
K_{\mathrm{r}}= & 0.00436 \text { (iron) }-0.00412 \text { (organic carbon) }-0.000294 \text { (sand) } \\
& +0.00121 \text { (very fine sand) }+0.00551
\end{aligned}
$$

where iron, organic carbon, sand and very fine sand are given as percentages. 
Journal of Hydrology 142 (1993): 251-271

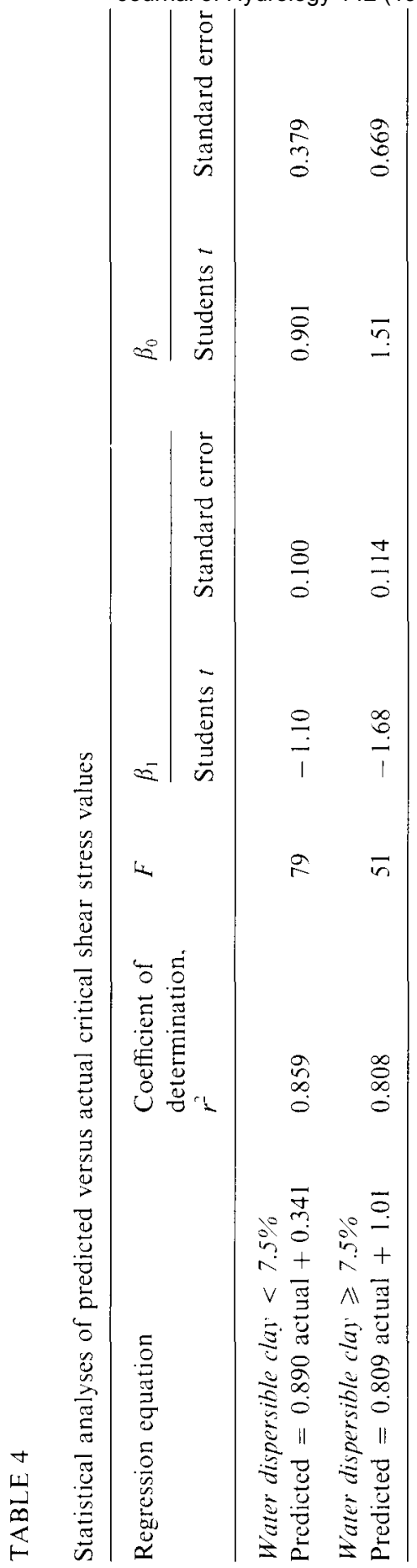




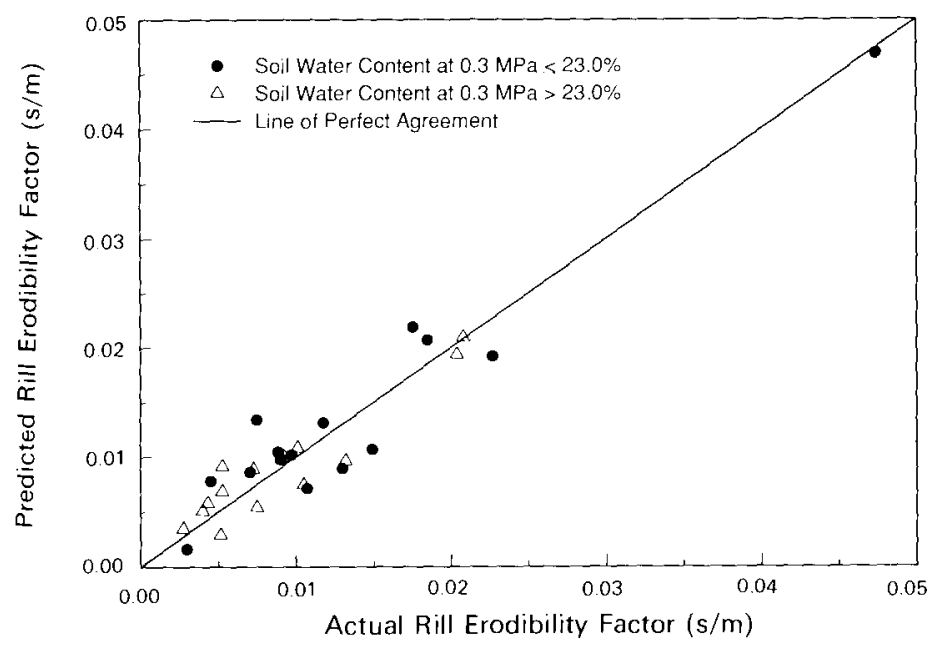

Fig. 5. Predicted vs. actual rill erodibility factors.

The regression coefficients shown in eqn. (9) were significantly different from zero at the $95 \%$ confidence level.

Soil survey data and eqns. (8) and (9) were used to calculate values of $K_{\text {r }}$ for each of the experimental soils. Results of the analyses are presented in Fig. 5. Predicted and actual values of $K_{\mathrm{r}}$ shown in Fig. 5 can be seen to be similar.

Linear regression analyses were used to compare predicted and actual values of $K_{\mathrm{r}}$. Results of the statistical analyses are presented in Table 5 . Equations (8) and (9) produced coefficient of determination values of 0.915 and 0.865 , respectively.

The hypotheses that the regression coefficients shown in Table 5 equal unity and the intercepts equal zero were evaluated at the $95 \%$ confidence level using the students $t$-test. The slopes were not significantly different from unity nor were the intercepts significantly different from zero. Thus, analyses of the experimental data suggests that eqns. (8) and (9) can be used to estimate rill soil erodibility factors.

\section{CRITICAL FLOW RATES}

\section{Identifying critical flow rates}

Flow rate versus slope-adjusted detachment capacity for the Barnes soil in North Dakota is shown in Fig. 6. Results obtained for this soil are also representative of the other experimental locations. It can be seen from Fig. 6 that the relationship between flow rate and slope-adjusted detachment 


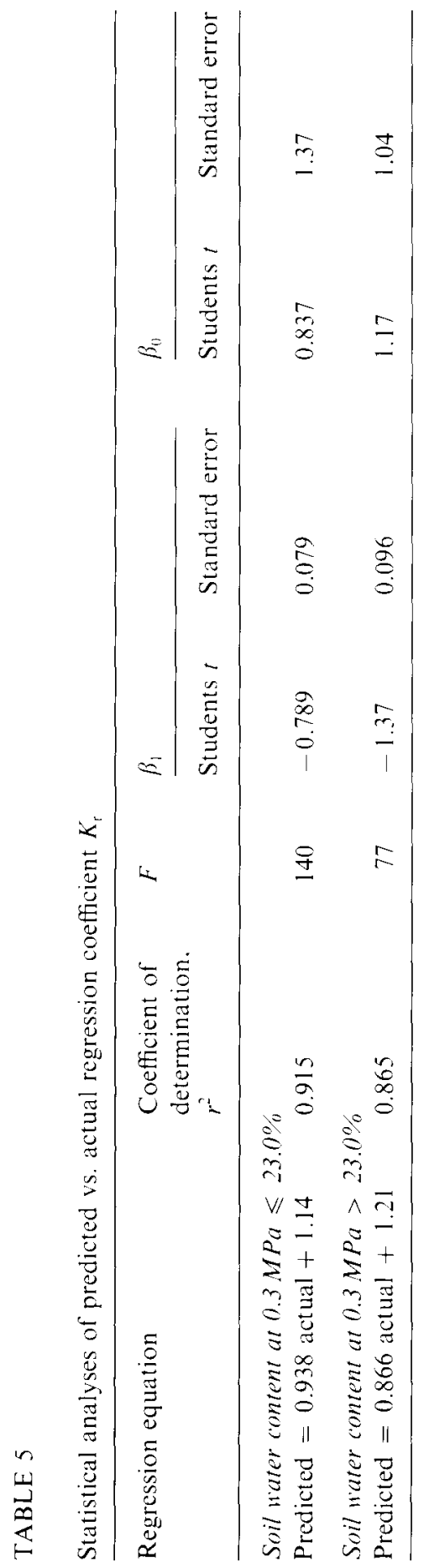




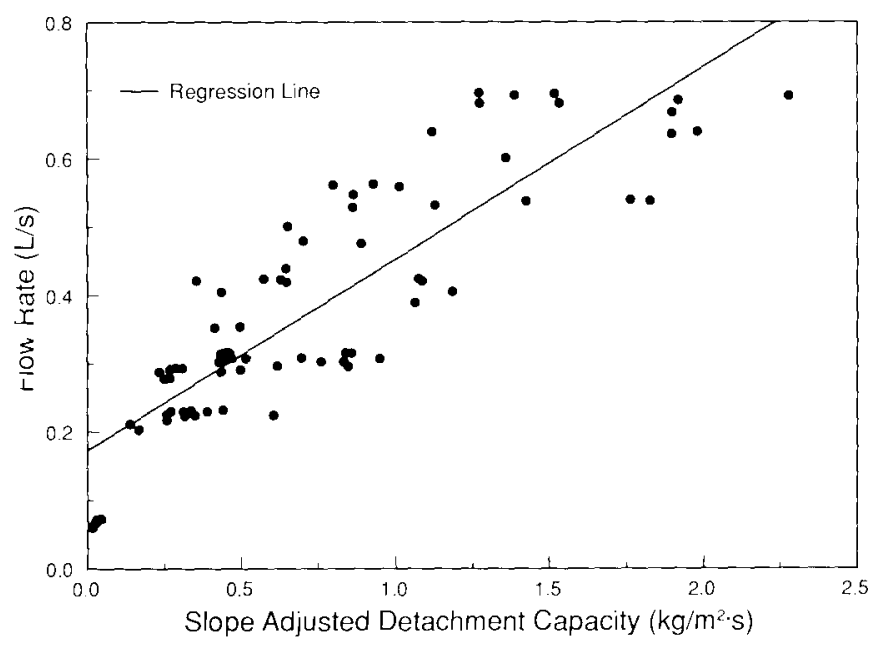

Fig. 6. Flow rate vs. slope adjusted sediment detachment capacity for a Barnes soil in North Dakota.

capacity can be well represented by a linear equation. Critical flow rate for initiation of rilling for the Barnes soil in North Dakota was 0.173 Is '.

Linear regression analyses were used to identify the critical flow rate values shown in Table 6 . Flow rates required to initiate rilling varied widely between study locations. Critical flow rates ranged from 0.00247Is ' for the Miami soil to $0.2171 \mathrm{~s}$ ' for the Pierre soil.

\section{Relating critical flow rates to soil properties}

Critical flow rate values identified in Table 6 were related to soil properties presented in Table 2 using step-wise multiple regression analyses. Statistical analyses suggested that critical flow rates were significantly correlated to silt content. For sites with silt content of $37.0 \%$ or less,

$$
\begin{aligned}
Q_{c}= & 0.222 \text { (aluminum) }+0.0171 \text { (cation exchange capacity) } \\
& -0.0223 \text { (magnesium) }-0.00984 \text { (soil water content } \\
& \text { at } 0.3 \mathrm{MPa})+0.00204 \text { (very fine sand) }+0.108
\end{aligned}
$$

where aluminum concentration, soil water content at $0.3 \mathrm{MPa}$ and very fine sand are given as a percentage, and cation exchange capacity and magnesium -content are in centimoles per kilogram. The regression coefficients shown in :qn. (10) were significantly different from zero at the $90 \%$ confidence level.

For sites with silt content greater than $37.0 \%$

$$
\begin{aligned}
Q_{c}= & 0.00373(\text { calcium })+0.0189(\text { magnesium }) \\
& +0.0966 \text { (organic carbon })-0.0537 \text { (potassium }) \\
& +0.00462(\text { soil water content at } 0.3 \mathrm{MPa})-0.130
\end{aligned}
$$


TABLE 6

Statistical analyses of equations used to relate rill flow rate to detachment capacity

\begin{tabular}{|c|c|c|c|}
\hline Soil & $\begin{array}{l}Q_{\mathrm{c}}^{\mathrm{a}} \\
\left(\mathrm{ls}^{\mathrm{l}}\right)\end{array}$ & $\begin{array}{l}K_{\mathrm{f}}^{\mathrm{a}} \\
\left(\mathrm{kgl}{ }^{1} \mathrm{~m}^{-2}\right)\end{array}$ & $\begin{array}{l}\text { Coefficient of determination, } \\
r^{2}\end{array}$ \\
\hline Academy & 0.177 & 9.23 & 0.658 \\
\hline Amarillo & 0.164 & 29.3 & 0.613 \\
\hline Barnes-MN & 0.152 & 6.67 & 0.704 \\
\hline Barnes-ND & 0.173 & 3.57 & 0.754 \\
\hline Caribou & 0.198 & 1.22 & 0.624 \\
\hline Cecil & 0.0767 & 3.28 & 0.693 \\
\hline Collamer & 0.0747 & 7.07 & 0.809 \\
\hline Frederick & 0.0912 & 1.63 & 0.709 \\
\hline Grenada & 0.143 & 4.96 & 0.657 \\
\hline Heiden & 0.0947 & 8.36 & 0.614 \\
\hline Hersh & 1.500 & 9.72 & 0.638 \\
\hline Hiwassec & 0.00432 & 6.11 & 0.731 \\
\hline Lewisburg & 0.110 & 4.55 & 0.752 \\
\hline Manor & 0.122 & 4.76 & 0.855 \\
\hline Mexico & 0.132 & 2.31 & 0.678 \\
\hline Miami & 0.00247 & 6.42 & 0.730 \\
\hline Miamian & 0.0955 & 4.80 & 0.601 \\
\hline Nansene & 0.106 & 16.2 & 0.615 \\
\hline Opequon & 0.147 & 2.45 & 0.639 \\
\hline Palousc & 0.115 & 6.00 & 0.731 \\
\hline Picrre & 0.217 & 13.8 & 0.609 \\
\hline Portneuf & 0.140 & 13.3 & 0.669 \\
\hline Sharpsburg & 0.153 & 3.53 & 0.734 \\
\hline Sverdrup & 0.166 & 10.5 & 0.612 \\
\hline Tifton & 0.125 & 4.58 & 0.703 \\
\hline Whitney & 0.0880 & 9.90 & 0.647 \\
\hline Williams & 0.203 & 3.70 & 0.629 \\
\hline Woodward & 0.0602 & 7.61 & 0.653 \\
\hline Zahl & 0.184 & 12.3 & 0.640 \\
\hline
\end{tabular}

"Regression coefficients $Q_{c}$ and $K_{\mathrm{f}}$ are used in the cquation $Q=\frac{1}{K_{\mathrm{t}}}\left(\frac{D_{\mathrm{c}}}{S^{3 / 2}}\right)+Q$

where flow rate and detachment capacity are in liters per second and kilograms per square meter per second, respectively, and slope is given as a fraction. 


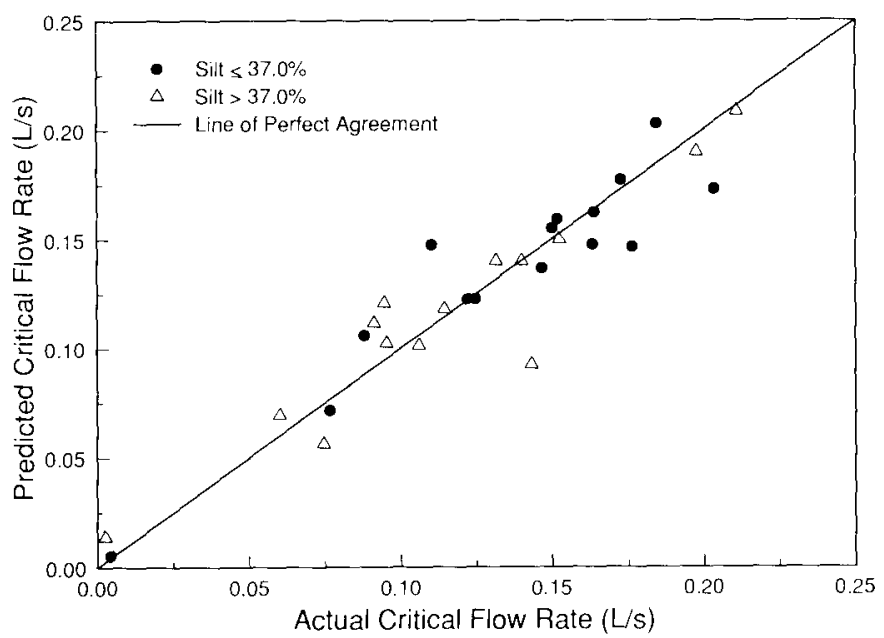

Fig. 7. Predicted vs, actual critical flow rates.

where calcium, magnesium, and potassium are in centimoles per kilogram, and organic carbon and soil water content at $0.3 \mathrm{MPa}$ are given as a percentage. All the regression coefficients shown in eqn. (11) were significantly different from zero at the $90 \%$ confidence level.

Values of $Q_{c}$ were calculated for each of the experimental soils using soil survey data and eqns. (10) and (11). Results of the analyses are shown in Fig. 7. Predicted and actual values of $Q_{c}$ shown in Fig. 7 can be seen to be similar.

Linear regression analyses were used to compare predicted and actual values of $Q_{c}$. Results of the statistical analyses are shown in Table 7. Coefficient of determination values of 0.878 and 0.882 were found for eqns. (10) and (11), respectively.

The Students $t$-test was used to evaluate the hypotheses that the regression coefficients shown in Table 7 equal unity and the intercepts equal zero at the $95 \%$ confidence level. The slopes were not significantly different from unity nor were the intercepts significantly different from zero. Thus, analyses of the experimental data suggests that eqns. (10) and (11) can be used to estimate $Q_{\text {c }}$.

\section{FLOW-RELATED RILL SOIL ERODIBILITY FACTORS}

\section{Identifying flow-related rill soil erodibility factors}

Figure 6 shows flow rate versus slope-adjusted detachment capacity for the Barnes soil in North Dakota. The flow-related rill soil erodibility factor is represented by the inverse of the slope of the regression line presented in Fig. 6. For the Barnes soil in North Dakota, the slope of the regression line was 


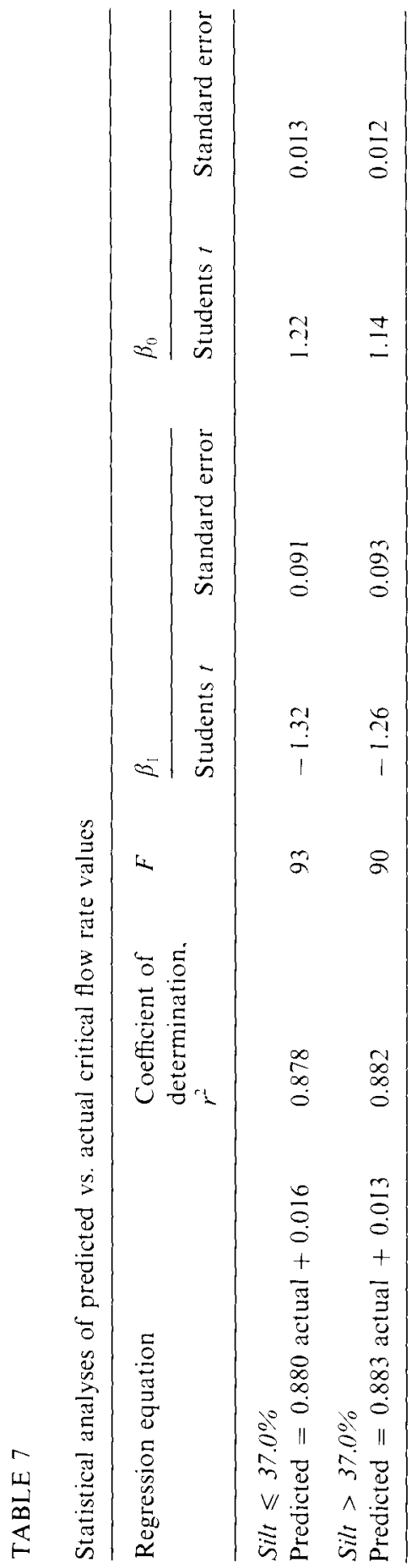


0.280 , which corresponds to a flow-related rill soil erodibility factor of $3.57 \mathrm{kgl}^{-1} \mathrm{~m}^{-2}$.

Flow-related rill soil erodibility factors were determined for each of the other study locations using linear regression analyses. Results of the regression analyses are shown in Table 6. Flow-related rill soil erodibility factors were found to vary from $1.22 \mathrm{kgl}^{1} \mathrm{~m}^{-2}$ for the Caribou soil to $29.3 \mathrm{kgl}^{-1} \mathrm{~m}^{-2}$ for the Amarillo soil.

\section{Relating flow-related rill soil erodibility factors to soil properties}

Step-wise multiple regression analysis was used to relate the flow-related rill soil erodibility factors identified in Table 6 to soil properties presented in Table 2. The flow-related rill soil erodibility factors were found to be significantly correlated to sand content. For sites with sand content of $40.0 \%$ or less,

$$
\begin{aligned}
K_{\mathrm{f}}= & -245 \text { (coefficient of linear extensibility) }+0.971 \text { (clay) } \\
& +0.336 \text { (silt) }+0.275 \text { (soil water content at } 0.3 \mathrm{MPa}) \\
& +1.04 \text { (very fine sand) }-43.9
\end{aligned}
$$

where coefficient of linear extensibility is in centimeters per centimeter and clay, silt, soil water content at $0.3 \mathrm{MPa}$, and very fine sand are given as a percentage. All the regression coefficients shown in eqn. (12) were significantly different from zero at the $90 \%$ confidence level.

For sites with sand content greater than $40.0 \%$,

$K_{\mathrm{f}}=329$ (coefficient of linear extensibility) +76.3 (sodium)

-20.3 (potassium) -0.743 (water dispersible clay) +11.7

where coefficient of linear extensibility is in centimeters per centimeter, sodium and potassium are in centimoles per kilogram, and water dispersible clay is given as a percentage. All the regression coefficients shown in eqn. (13) were significantly different from zero at the $90 \%$ confidence level.

Values of $K_{\mathrm{f}}$ were calculated for each of the experimental soils using soil survey data and eqns. (12) and (13). Results of the analyses are shown in Fig. 8. Predicted and actual values of $K_{f}$ shown in Fig. 8 can be seen to be similar.

Linear regression analyses were used to compare predicted and actual values of $K_{\mathrm{f}}$. Results of the statistical analyses are presented in Table 8 . Equations (12) and (13) produced coefficient of determination values of 0.906 and 0.837 , respectively.

The Students $t$-test was used to evaluate the hypotheses that the regression coefficients shown in Table 8 equal unity and the intercepts equal zero at the $95 \%$ confidence level. The slopes were not significantly different from unity 


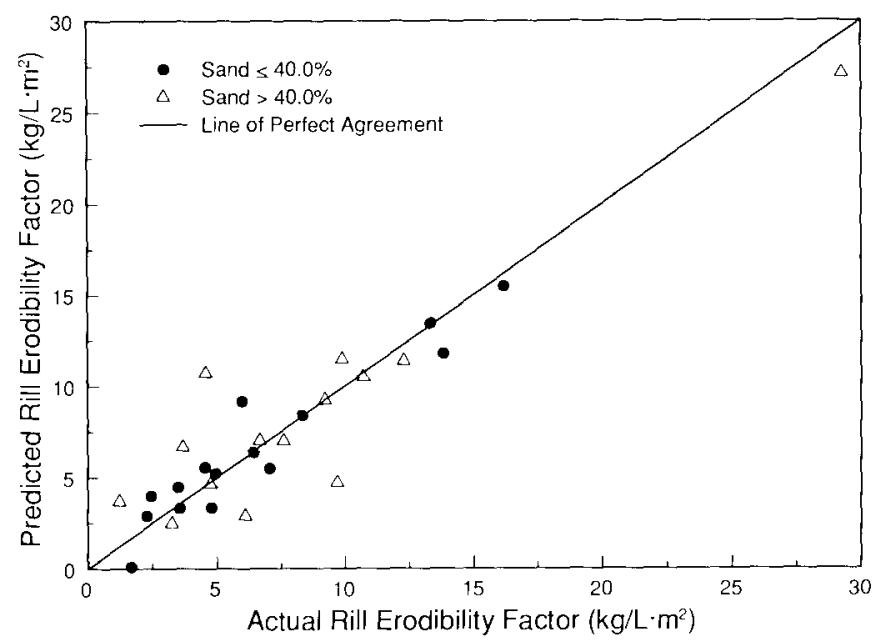

Fig. 8. Predicted vs. actual flow related rill erodibility factors.

nor were the intercepts significantly different from zero. Thus, analyses of the experimental data suggests that eqns. (12) and (13) can be used to estimate flow-related rill soil erodibility factors.

\section{LIMITATIONS OF THE REGRESSION EQUATIONS}

Although reasonable estimates of critical shear stress and critical flow rates were provided by the regression equations, other factors may limit their application in field situations. For example, crop residues and rock fragments were absent from the sites where the experimental data used to parameterize the regression equations were obtained. Crop residue cover could serve to protect rill and interrill areas from soil detachment. Soil detachment may also decrease as channel armoring develops, if soils contain rock fragments. Critical shear stress and critical flow rates for sites where crop residue or rock fragments are present may be substantially larger than estimates obtained using equations presented in this study.

Temporal variations in critical shear stress and critical flow rates may also occur. These differences have been attributed to changes in soil cohesion, rainfall-induced soil consolidation, and development of root fabric. Critical shear stress and critical flow rates identified in this study are strictly applicable only for conditions immediately following tillage. At present, procedures for estimating temporal effects on critical shear stress and critical flow rates have not been identified.

Values of $K_{\mathrm{r}}$ and $K_{\mathrm{f}}$ were determined for bare unconsolidated soil conditions existing immediately after tillage. Soil erodibility may be affected 
Gilley, Elliot, Laflen \& Simoanton

Journal of Hydrology 142 (1993): 251-271

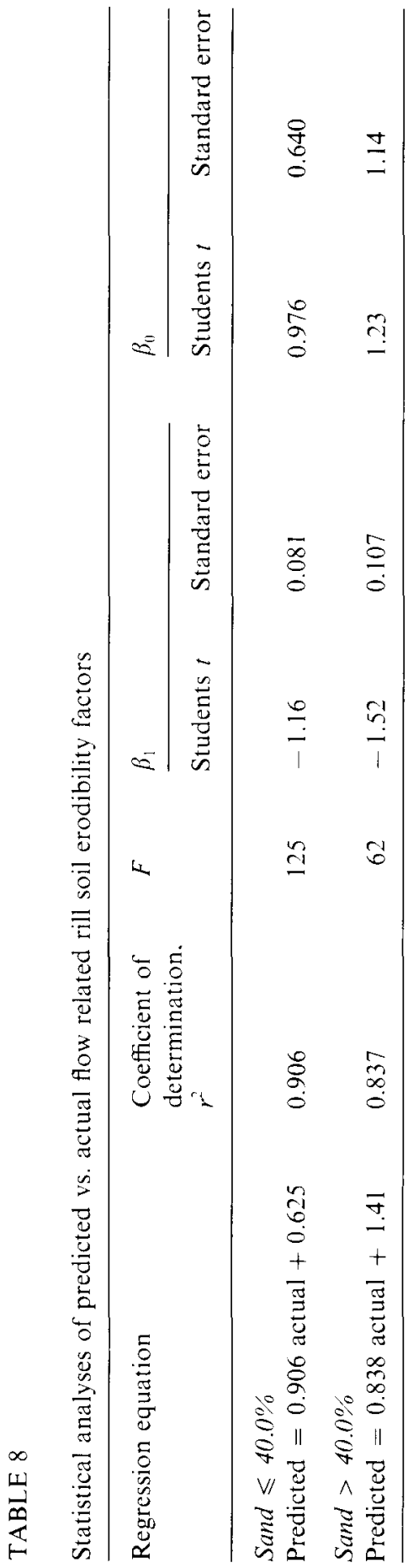


by soil consolidation, below-ground residue, and freeze-thaw conditions. Methods for calculating the effects of soil consolidation on erodibility were identified by Nearing et al. (1988). Brown et al. (1989) developed relationships for adjusting rill erodibility for below-ground residue.

This study was conducted on cropland soils where surface residue had been removed and the areas were maintained free of vegetation for several months. The sites were tilled immediately before testing and were, therefore, in a highly erosive condition. The regression equations developed in this study should not be applied to pasture or rangeland areas with much different soil and vegetative characteristics.

\section{SUMMARY AND CONCLUSIONS}

Hydraulic conditions required to initiate rilling were identified in this study. Linear equations were used to relate shear stress values and flow rates to rill sediment detachment capacity. The intercept of the linear equations provided estimates of critical shear stress and critical flow rate.

Runoff and erosion data collected on soils located throughout the USA were used to determine critical shear stress values and critical flow rates. The experimental sites were selected to cover a broad range of soil properties. On each of the sites, crop residue had been removed, moldboard plowing and disking had occurred, and preformed rills had been constructed.

Selected soil properties were measured at each of the experimental locations. Critical shear stress values and critical flow rates were related to site-specific soil properties using multiple regression analysis. Close agreement was found between predicted and actual values.

Process-based models for predicting runoff and erosion on upland areas require information on flow hydraulics and soil erodibility. Procedures for estimating hydraulic conditions required to create rills were identified in this investigation. This information will improve our ability to understand and properly model upland runoff and erosion processes.

\section{ACKNOWLEDGMENTS}

This paper is a contribution from USDA-ARS, in cooperation with the Agricultural Research Division, University of Nebraska, Lincoln, and is published as Journal Series No. 9647.

\section{REFERENCES}

Brown, L.C., Foster, G.R. and Beasley, D.B., 1989. Rill erosion as affected by incorporated crop residue and seasonal consolidation. Trans. ASAE, 32(6): 1967-1978. 
Elliot, W.J., Liebenow. A.M., Laflen, J.M. and Kohl, K.D., 1989. A compendium of soil erodibility data from WEPP cropland soil field erodibility experiments 1987 and 88 . NSERL Rep. No. 3, USDA-ARS, West Lafayette, IN, $317 \mathrm{pp}$.

Foster, G.R., 1982. Modeling the erosion process. In: C.T. Hatan, H.P. Johnson and D.L. Brakensick (Editors), Hydrologic Modeling of Small Watersheds. American Society of Agricultural Engineers, St. Joseph, MI, pp. 297-380.

Laursen, E.M., 1958. The total sediment load of streams. J. Hydraul. Div., ASCE 123(1): $195-206$.

Nearing, M.A., West, L.T. and Brown, L.C., 1988. A consolidation model for estimating changes in rill erodibility. Trans. ASAE, 31(3): 696-700.

Nearing, M.A., Foster, G.R., Lane, L.J. and Finkner. S.C.. 1989. A process-based soil crosion model for USDA-Water Erosion Prediction Project technology. Trans. ASAE, 32(5): $1587-$ 1593.

Schoklitsch, A., 1957. River bed degradation below large capacity reservoir. Trans. ASCE, 122: 688-695.

Soil Survey Staff, 1984. Procedures for collecting soil samples and methods of analysis for soil survey. USDA-SCS Soil Survey Investigations Rep. No. 1., U.S. Government Printing Office, Washington, DC.

Swanson, N.P., 1965. Rotating-boom rainfall simulator. Trans. ASAE, 8(1): 71-72. 